\title{
An Empirical Study of Chinese Manufacturing Listed Companies' Merger Performance
}

\author{
Chao-Yang XU*, Chen-Chen WANG, Xiong-Fei LIU \\ Accounting School, Wuhan Textile University, Wuhan Hubei, China \\ Email: 369176366@qq.com, \\ *Corresponding author
}

\begin{abstract}
In this text, we conduct empirical analysis on performance of China's manufacturing listed companies from the perspective of M\&A. Taking 285 China's manufacturing listed companies whose $M \& A$ is occurred and completed between the year of 2010 and 2013 as object, and adopting the financial index analysis methods, we research the impact of different types of merger and acquisition and different scales to merger and acquisition performance of companies, and discuss the choice of the merger and acquisition ways and orientation of target companies' scale. We finally discover that horizontal mergers and acquisitions have the best performance, and secondly the vertical M\&A, but conglomerate M\&A have the poorest performance, and the scale of acquired companies has no relevance to merger and acquisition performance. Thus we can come to a conclusion; M\&A of companies should focus more on integration of existing industries, rather than blindly pursue diversified operation.
\end{abstract}

Keywords- Manufacturing, Scale of M\&A, Merger type, M\&A performance.

\section{INTRODUCTION}

With the rapid development of internet technology and intellectual technology, many developed countries put forward the re-industrialization strategies which consider the revival of manufacturing industry as the core successively, combining internet with manufacturing industry, and starting the period of 4.0 in industry. Manufacturing industry is the mainstay industry in our country. Its development state and prospect have direct impact on our country's healthy and stable development and comprehensive national power. The problems such as demographic dividend's wearing off, lack of capacity of independent innovation appear to be increasingly urgent. In such situation, companies launch M\&A in succession, in order to acquire excess earnings and companies' long term development. Successful M\&A can not only help to the expanding of companies' scales and the cost saving, but also achieve synergistic effect and promotion of companies' transformation and upgrading. In this text, through the way of collecting totally six years' financial indexes of manufacturing listed companies of stock markets of Shanghai and Shenzhen of A-shares, we analyze the impact of different types of M\&A and different scales on the performance of merger and acquisition, and we get insight of the ways and scales of companies' mergers and acquisitions, thus improving the performance of M\&A.

\section{RESEARCH DESIGN}

\section{A. Data Sources and Sample Selection}

In this text, we consider the first notice date as the day of M\&A, selecting manufacturing A-share listed companies whose M\&A occurred in the period from 2010 to 2013 in sequence database as initial sample. And we collected data of financial index of various companies in Oriental Fortune free version. We sifted the sample and data above based on the criteria below:

(1)Acquired companies need to be listed two or three years before the year of M\&A, and do not be delisted till now, and not the companies of ST and *ST, and M\&A have finished.

(2)We remove the data of the companies whose M\&A is in progress or unsuccessful up to September $31^{\text {st }} 2013$.

(3)We remove the data of companies or years of which financial data is incomplete.

(4)The M\&A occurred between the same buyer and more than one sellers in different years are considered as multiple transaction.

(5)The M\&A occurred between the same buyer and only one seller are considered as one-time transaction, and we considered the least M\&A as standard.

We finally got 1690 sample data.

\section{B. Research Method and Hypothesis}

In this text, we adopt methods of financial index. Through the analysis of the return on equity(ROE) in the year from 2010 to 2013 of companies whose M\&A occurred in the period from 2009 to 2015, we get knowledge of the performance of the acquired companies before and after the M\&A. After summarizing the existing researches, we find the following things. Some scholars believe that the performance of horizontal M\&A is most steady, and the performance of vertical M\&A is the best, but conglomerate M\&A have the poorest performance. In addition, the scales of companies have negative correlation to performance. However, the research of the relationship between the relative scale and performance is few, so we cannot draw a definite conclusion. Given this, we come to the hypothesis below. 
Hypothesis 1: horizontal M\&A has significant correlation to M\&A performance, and horizontal M\&A can steadily increase companies' performance.

Hypothesis 2: vertical M\&A has significant correlation to M\&A performance, and vertical M\&A can increase companies' performance but worse than horizontal M\&A.

Hypothesis3: conglomerate M\&A has significant correlation to M\&A performance, and conglomerate M\&A will reduce companies' performance.

Hypothesis4: The relative scale of acquired companies is different. The performances arising from companies' acquisition after $\mathrm{M} \& \mathrm{~A}$ have significant difference, and performances have positive correlation to scales. The bigger the relative scale of the acquired company, the better the performance is. Conversely, the smaller the relative scale of the acquired company, the worse the performance is.

\section{EMPIRICAL RESULT}

\section{A. Selection and Expression of Variable}

This paper only selects representative financial indicators, ROE to measure the performance of M\&A, and using SPSS software.ROE is considered to be the dependent variable, the type of $M \& A$ and $M \& A$ funds accounted capital ratio is considered to be independent variables. We study the effects of independent variables on the dependent variable. The variables and their definitions adopted in this text areshown in Table 1:

TABLE I. VARIABLES AND DESCRIPTIONS

\begin{tabular}{|c|c|c|c|c|}
\hline Variable & Variable name & $\begin{array}{l}\text { Variable } \\
\text { symbol }\end{array}$ & Variable definitions & comment content \\
\hline $\begin{array}{l}\text { dependent } \\
\text { variable }\end{array}$ & ROE & $\mathrm{Yi}$ & Net profit /Average net assets(\%) & M\&A Performance \\
\hline \multirow{2}{*}{$\begin{array}{l}\text { independent } \\
\text { variables }\end{array}$} & $\begin{array}{l}\text { the type of } \\
\text { M\&A }\end{array}$ & $\mathrm{x} 1$ & $\begin{array}{l}\text { HorizontalM\&A as } 1 \text { and vertical M\&A as } 2 \text { and } \\
\text { mixed M\&A as } 3\end{array}$ & - \\
\hline & $\begin{array}{c}\text { M\&A funds accounted } \\
\text { capital ratio }\end{array}$ & $\mathrm{x} 2$ & M\&A funds /Total assets(\%) & Scale M\&A \\
\hline \multirow{7}{*}{ Control variables } & \begin{tabular}{|c|} 
Growth \\
\end{tabular} & $\mathrm{B} / \mathrm{M}$ & $\mathrm{B} / \mathrm{M} \mathrm{s}$ ratio & - \\
\hline & $\begin{array}{c}\text { Ownership } \\
\text { Concentration }\end{array}$ & share & $\begin{array}{l}\text { The proportion of the acquiring company's largest } \\
\text { shareholder }\end{array}$ & 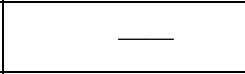 \\
\hline & Cash Flow & cash & $\begin{array}{l}\text { Net cash flow from operating activities /total } \\
\text { assets }\end{array}$ & $\begin{array}{l}\text { Total assets cash } \\
\text { recoveries }\end{array}$ \\
\hline & Financial Leverage & lev & $\begin{array}{l}\text { The ratio of the acquiring company's total } \\
\text { liabilities and } \\
\text { equity }\end{array}$ & Equity ratio \\
\hline & payment method & payment & If you take the cash payment to "1", 0 otherwise & - \\
\hline & Ownership & SOE & $\begin{array}{l}\text { If the value of state-owned enterprises is "1", } \\
\text { otherwise "0" }\end{array}$ & - \\
\hline & Year dummies & Year & $\begin{array}{l}6 \text { year dummy acquisitions occurred in } \\
2009-20157 \text { year run }\end{array}$ & - \\
\hline
\end{tabular}

\section{B. Descriptive Statistics and Empirical Results}

1. Descriptive Statistics

TABLE II. DESCRIPTIVE STATISTICAL OF EACH VARIABLE

\begin{tabular}{|c|c|c|c|c|c|c|c|c|}
\hline \multirow{2}{*}{ variable } & \multicolumn{2}{|c|}{$\mathrm{N}$} & \multirow{2}{*}{ Means } & \multirow{2}{*}{ Median } & \multirow{2}{*}{ Majority } & \multirow{2}{*}{ SD } & \multirow{2}{*}{ Minimum } & \multirow{2}{*}{ Maximum } \\
\hline & effective value & Missing & & & & & & \\
\hline M\&A Type & 1690 & 0 & 1.7941 & 1 & 1 & 0.8875 & 1 & 3 \\
\hline $\begin{array}{l}\text { M\&A funds } \\
\text { accounted capital } \\
\text { ration }\end{array}$ & 1690 & 0 & 0.9913 & 0.42 & 0.08 & 1.86125 & 0.02 & 17.99 \\
\hline ROE & 1690 & 0 & 9.2906 & 8.475 & 0 & 13.69521 & -108.62 & 77.48 \\
\hline
\end{tabular}

As it can be seen from table 2:(1)M\&A funds accounted capital ration maximum, the mean and median are significant difference, It occurred between 2010-2013 showed that " big eat small" M\&A events are more frequent,
At the same time, part of the "small eat big " incident occurred in the acquired business is relatively larger, indicating the frequency distribution of acquisitions of all sizes are more concentrated.(2)Average ROE is greater than 
the median, Standard deviation is about 13.69521 , indicating that the concentration is not high, more dispersed, Further illustrate the large M\&A performance differences between different enterprises, which is consistent with the maxima and minima ROE values differ greatly. ROE standard deviation is greater than M\&A funds accounted capital ration standard deviation is because ROE is a measure of the performance of the enterprise, M\&A funds accounted capital ration is a measure of the relative size of the acquired business, the more limited range.

C. Correlation Analysis

TABLE III. PEARSON CORRELATION ANALYSIS

\begin{tabular}{|c|c|c|c|}
\hline variable & $\mathrm{x} 1$ & $\mathrm{x} 2$ & $\mathrm{Y}$ \\
\hline $\mathrm{x} 1$ & $\begin{array}{c}1.000 \\
(0.000)\end{array}$ & & \\
\hline $\mathrm{x} 2$ & $\begin{array}{c}0.203^{* *} \\
(0.000)\end{array}$ & $\begin{array}{c}1.000 \\
(0.000)\end{array}$ & \\
\hline $\mathrm{y}$ & $-0.067^{*}$ & 0.012 & 1.000 \\
& $(0.006)$ & $(0.621)$ & $(0.000)$ \\
\hline
\end{tabular}

The p-value are reported in parentheses. $* * *, * *$, and * indicate significance at the 0.01,0.05 and 0.1 levels, respectively.

Table 3 shows that:(1)Correlation between the level of $y$ and $\mathrm{x} 1$ is negative, and the significance level is 0.006 ,indicating ROE and M\&A Type showed a significant negative correlation at the level of 0.01 . Verified hypotheses 1 and 2, hypotheses 3 did not pass. This may be because Horizontal M\&A is carried out in the original source chain can bring synergies and economies of scale for the enterprise, Increase market share and competitiveness. Vertical M\&A is throttled in the original industrial chain through the effective integration of upstream and downstream resources, reduce costs and improve the competitiveness of enterprises; mixed M\&A is with the original chain of independent industry, Although the risk of a single industry can be dispersed, but into a new industry has no direct positive impact on the integration of existing industrial chain. But because of lack of business experience, technical personnel, social relations as a result of funding strand breaks, thus affecting the development of the whole enterprise, the greater risk. (2) $\mathrm{y}$ and $\mathrm{x} 2$ are positive in correlation levels, but the significance level is 0.621 , did not pass the test of significance, This indicates that ROE and $M \& A$ funds accounted capital ration relationship is not significant, so that hypothesis 4 has not been effectively verified. This is because when the acquired company is at a relatively large scale, the acquisition cost of enterprises in the organizational structure of savings, customers and sales increase, conducive to the formation and synergies of economies of scale, can effectively improve business performance; When a relative smaller size of the acquired company, the support of of the acquired business enterprise and improve the performance of the acquired company is still able to make post-merger effectively improve. Regardless of the relative size of the acquired business is large or small, to a certain extent, are able to improve the performance of enterprises, The difference is that the number of performance improvement.

\section{Multiple Linear Regression ANALYSIS}

In order to validate assumptions, establish the following model

$$
\mathrm{Y}=\mathrm{a} \times 1+\mathrm{b} \times 2+\varepsilon(1)
$$

$\mathrm{X} 1$ is M\&A Type, $\mathrm{x} 2$ is the merger of funds accounted for capital ratio, $\mathrm{Yi}$ is the dependent variable, showing the performance before and after M\&A in each year.

TABLE IV.

\begin{tabular}{|c|c|c|c|c|c|}
\hline model & $\mathrm{R}$ & $\mathrm{R}$-squared & Adjusted R-squared & Std.Error & Durbin-Watson \\
\hline 1 & 0.071 & 0.005 & 0.004 & 13.66834 & 0.294 \\
\hline
\end{tabular}


TABLE V. ANOVA

\begin{tabular}{|c|c|c|c|c|c|c|}
\hline \multicolumn{2}{|c|}{ model } & sum of square & df & Mean Square & F & Sig. \\
\hline \multirow{2}{*}{1} & return & 1615.763 & 2 & 807.882 & 4.324 & .013 \\
& Residuals & 315171.143 & 1687 & 186.823 & \\
& total & 316786.906 & 1689 & & \\
\hline
\end{tabular}

As we can see from table 5, the regression squares of the regression model is far less than the residual sum of squares, indicating the total linear model explained only a small part of the square, this summary is consistent with adjusted R-square in the model table. Both indicate that the equation fitting result is not ideal, cannot explain the linear relationship between the independent variables and the dependent variable.

TABLE VI. COEFFICIENT A

\begin{tabular}{|c|c|c|c|c|c|c|c|c|}
\hline & & \multicolumn{2}{|c|}{$\begin{array}{c}\text { Non-standardized } \\
\text { coefficients }\end{array}$} & \multirow[t]{2}{*}{$\begin{array}{l}\text { standardized } \\
\text { coefficients } \\
\end{array}$} & \multirow[b]{2}{*}{$\mathrm{t}$} & \multirow[b]{2}{*}{ Sig. } & \multicolumn{2}{|c|}{ Collinearity statistics } \\
\hline \multicolumn{2}{|c|}{ model } & B & Standard error & & & & Tolerance & VIF \\
\hline & (constant) & 11.087 & 0.751 & & 14.759 & 0.000 & & \\
\hline \multirow[t]{2}{*}{1} & $\mathrm{x} 1$ & -1.109 & 0.383 & -0.072 & -2.899 & 0.004 & 0.959 & 1.043 \\
\hline & $\mathrm{x} 2$ & 0.196 & 0.182 & 0.027 & 1.072 & 0.284 & 0.959 & 1.043 \\
\hline
\end{tabular}

From table 6, M\&A type is significantly associated with firm performance, but the relationship between scale M\&A and corporate performance shows there does not exist significant correlation relationship between the two variables. This is consistent with the correlation analysis and Anova analysis, and significance level of constant is zero, indicating that the constant through significant test. From table 6 and the above analysis model is obtained: $\mathrm{y}=$ $-1.109 \times 1+0.196 \times 2+11.087$.In addition, the co-linear statistics VIF between 2 variables is 1.043, Further indicates that there is no collinearity between M\&A Type and acquisitions scale, Further show evidence of M\&A performance was significantly related to M\&A type, and regardless of the the scale of M\&A.

\section{CONCLUSION AND SUGGESTIONS}

In this text, aimed at M\&A in manufacturing industry occurred in the period from 2010 to 2013, adapting the method of financial index, and considering the financial data in specific terms as object, we conduct research of M\&A's impact on M\&A performance, and finally come to a conclusion: When determining the strategic direction of a company, acquiring the companies relevant to existing industry, integrate industry chain, concentration of strategic purpose, are all of great importance to improving companies' M\&A performance.

\section{ACKNOWLEDGEMENT}

This research was financially supported by Ministry of Education Humanities and Social Science Planning Fund.

\section{REFERENCES}

[1] Zhao Liping,Li Xinhua. An Empirical Study of Listed Companies' Merger Performance and Behavior Changes_-based on manufacturing data2006 -2009[J].communication of finance and accounting, 2012,06:53-55.

[2] Sumit K. Majumdar,RabihMoussawi,UlkuYaylacicegi. Merger Waves and Firm Growth: Contemporary Historical Evidence[J]. Annals of Public and Cooperative Economics,2013,841.

[3] Anja Trichterborn,DodoZuKnyphausen--Aufseß,LarsSchweizer. How to improve acquisition performance: The role of a dedicated M\&A function, M\&A learning process, and M\&A capability [J]. Strat. Mgmt. J.,2016,374.

[4] Du chuanzhong,Guoshulong. Effects and Mechanism of Enterprise Growth Analysis of M \&A[J]. Research on Financial and Economic Issues,2012, 12: 102-110.

[5] Xu Dandan. An Empirical Study of Chinese Listed Companies in 2006 M \& A value effect [J]. Technology and management, 2008,03:64-66.

[6] GuoGuanfu,HeJinguo,YuanQinyang. An Empirical Analysis of Foreign M \& A in Shanghai and Shenzhen listed companies in manufacturing performance [J]. economy Forum, 2008,01:110-113.

[7] Yu chengyong, Shi Jianjun, Fang Hong. Control over the size and performance of M\&A--An Empirical Study Based on Listed Companies in Shanghai and Shenzhen Manufacturing [J]. International trade issues, 2013,05:128-142. 
[8] Zhang Zheng, Nie Si. Innovation Performance of Chinese Management, 2016,04:36-43.

Manufacturing Listed Companies' Merger [J]. Research 